\title{
Fauna Associated with Brushwood Transposition in a Mining Area in the South of Brazil
}

Lucas Donato Toso ${ }^{1}$ (1) 0000-0003-0026-5714

Ana Paula Moreira Rovedder ${ }^{1}$ (D) 0000-0002-2914-5954

Rafaela Badinelli Hummel ${ }^{1}$ (D) 0000-0002-3251-6031

Aline Peccatti ${ }^{1}$ (D) 0000-0001-9453-7658

Elias Frank de Araújo 2 (1) 0000-0002-7635-5305

Roselene Marostega Felker ${ }^{1}$ (D) 0000-0003-3944-4381

José Carlos Corrêa da Silva Junior ${ }^{1}$ (1) 0000-0002-9417-0558

Frederico Neuenschwander ${ }^{1}$ (1) 0000-0002-3520-7680

\begin{abstract}
This study evaluates the potential of fauna attractiveness according to brushwood transposition in an abandoned mining area under restoration in Rio Grande do Sul, Brazil. Sixteen areas of brushwood measuring $2 \mathrm{~m}^{2}$ area and $1 \mathrm{~m}$ high were installed. The occurrence of fauna groups under and around the brushwood piles was then observed with use of bi-monthly surveys. Data were collected using a non-destructive method and the animals were identified by order and separated by taxonomic units. Twenty-three fauna orders were found, with the most frequent being Anura, Araneae, Hymenoptera and Isoptera. There was an increase in the number of taxonomic units found in each survey, with a significant difference after ten months of installation. The results indicate that the brushwood was attractive to the fauna and provided new habitats and coexistence between different fauna groups during the monitored period.
\end{abstract}

Keywords: ecological restoration, edaphic fauna, degraded area, mining.

\section{INTRODUCTION AND OBJECTIVES}

Mining has drastic effects on the soil, removing vegetation and exposing the deeper layers of the profile. Without any vegetation cover and resilience to promote natural regeneration, this activity promotes a gradual fragmentation of the local landscape (Cabral \& Albuquerque, 2012; Mechi \& Sanches, 2010).

The recovery of these areas is primarily based on reestablishing vegetation cover and chemical, physical and biological soil attributes (Oliveira Filho et al., 2014). However, simply revegetating an area does not guarantee its restoration, as this process tends to homogenize the environment and consequently reduce the diversity of fauna groups.

Thus, most studies tend to only evaluate the return and development of vegetation in ecological restoration processes
(Jesus et al., 2016; Pais \& Varanda, 2010). Studies addressing fauna communities in the restoration process are still incipient in Brazil (Vergílio et al., 2013). The fauna is generally a little addressed indicator in studies that use nucleating techniques for ecological restoration, including brushwood (Fragoso et al., 2017; Oliveira \& Engel, 2017).

One way to promote the relationship of fauna with mined areas under restoration is to offer new habitats which were previously non-existent at the site and tend to attract populations of different groups. Brushwood transposition consists of piles of forest residues or firewood allocated in the degraded area and act as a natural shelter for animals against predators and excessive solar heating (Reis et al., 2014).

This technique is suitable for areas affected by large soil removal, as piles of organic matter fully decompose over

${ }^{1}$ Universidade Federal de Santa Maria (UFSM), Santa Maria, RS, Brasil

${ }^{2}$ CMPC Celulose Riograndense, Guaíba, RS, Brasil 
time and form layers of humus, thereby restoring soil biota and providing appropriate shelter and microhabitats for developing basic food chain groups (Reis et al., 2010; Vergílio et al., 2013) that tend to become more complex over time.

Given this context, this study evaluated the attractiveness potential of fauna in terms of quality and quantity of fauna orders through transpositioning of brushwood in a mined area undergoing ecological restoration.

\section{MATERIALS AND METHODS}

\subsection{Study area}

The study area is located in Guaíba, RS (Figure 1) and consists of approximately 0.4 ha of a clay mining pit whose extraction activity was closed about 19 years ago. The area is characterized by exposed saprolite of granitic origin subjected to erosive processes intensified by the escarpment angle of the mining pit slope to the south. The area is also subjected to periodic flooding from a lake (Figure 1) on its north side. The vegetation cover is generally incipient and constituted of grasses and herbs, which confers low local resilience.

According to the Köppen classification, the climate of the region is Cfa, subtropical humid with hot summers and no defined dry season. The average annual rainfall is $1455 \mathrm{~mm}$, with an average temperature of $18.8^{\circ} \mathrm{C}$, a maximum of $24.4^{\circ} \mathrm{C}$ and a minimum of $13.9^{\circ} \mathrm{C}$ (Alvares et al., 2013).
The study region presents elements of a Semi-deciduous Seasonal Forest in an area of ecological stress in contact with the Pampa Biome, with the Seasonal Forest of the Atlantic Forest Biome being located to the north on the edge of the plateau. The surrounding vegetation matrix is characterized by a mosaic composed of Eucalyptus sp. (monoculture) and secondary forest fragments undergoing early natural regeneration. The soil was classified by Felker et al. (2018) as Haplic Cambisol of granitic origin.

\subsection{Implementation of brushwood}

The brushwood transposition was carried out in August 2016 to fill portions of soil without vegetation cover, randomly allocated and equally distributed in the area. Sixteen nuclei of $2 \mathrm{~m}^{2}$ in area and $1 \mathrm{~m}$ in height were transposed into the study area, which has approximately 0.4 ha.

The nuclei were composed of tree branches, leaves, trunks, seeds and flowers, as well as shrubs, herbaceous and liana species from early regeneration areas located approximately $1 \mathrm{~km}$ away from the study site.

The brushwood was placed on trellises made of green bamboo (Bambusa tuldoides Munro.) with dimensions of $2 \mathrm{~m} \times 1 \mathrm{~m}$ and tied with wire. This method is innovative and aimed at making the brushwood portable, having been developed for collecting variables below the nuclei with minimal interference on the ecological system in process of formation (Figure 2).

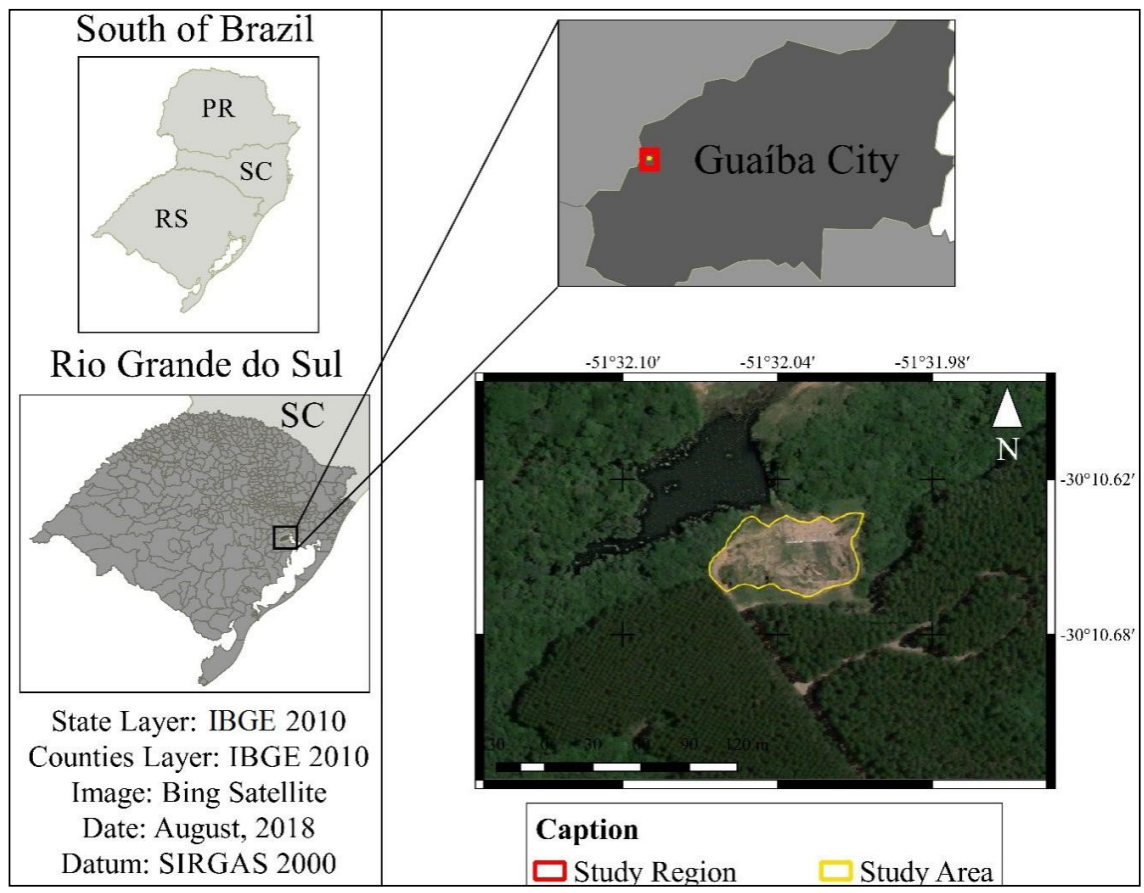

Figure 1. Location of the study area, characterized as an abandoned mining pit in the Guaíba County, Rio Grande do Sul, Brazil. 


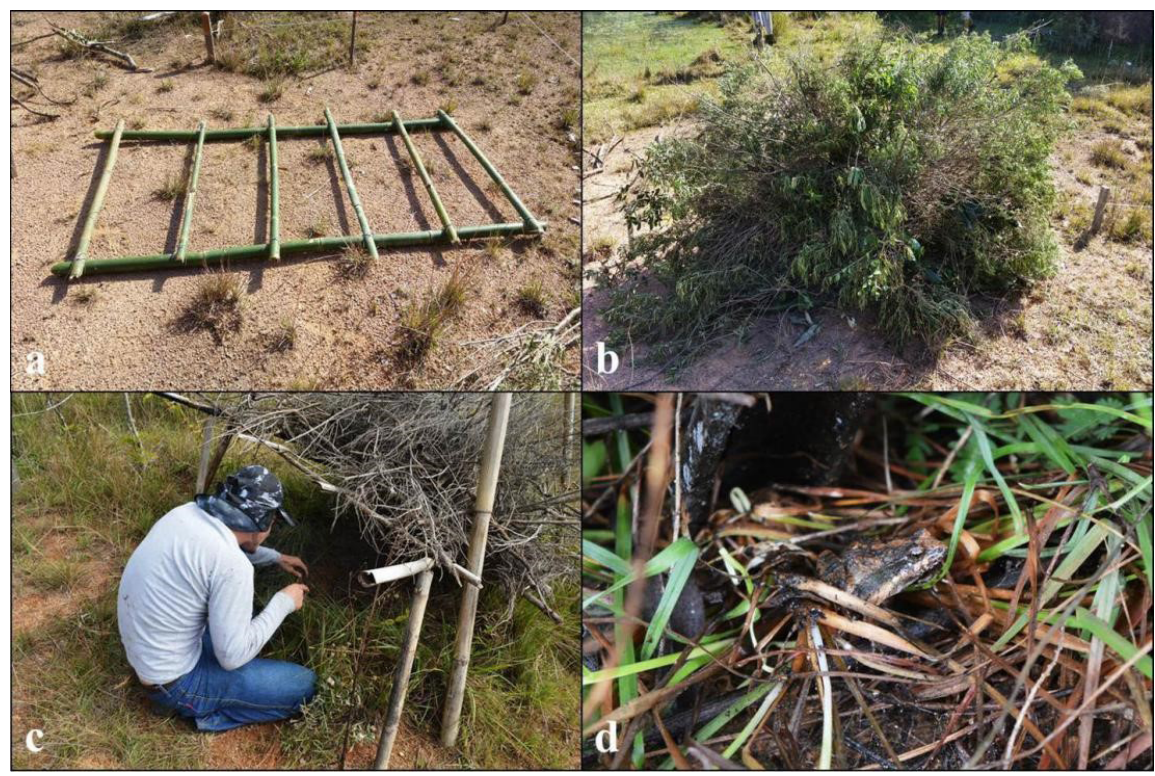

Figure 2. Brushwood and monitoring mechanism implementation: (a) bamboo trellis used as support; (b) brushwood arrangement; (c) brushwood monitoring; (d) environment under the brushwood during monitoring with occurrence of fauna groups.

\subsection{Data collection and analysis}

The evaluation was carried out over one year, starting from the brushwood implementation in August/2016. Fauna surveys were then performed every two months after the implantation, totaling six evaluations in October and December/2016, and then in February, April, June and August/2017.

The method was non-destructive with no removal of material or living organisms in order to interfere as little as possible in the fauna composition. This methodology was adopted so that the research could be carried forward while at the same time maintaining the positive effects of the technique on-site.

No individuals or traces of the fauna were observed under the brushwood interspersed with an organic matter layer on the edges and between the branches. The bamboo trellises were raised to an angle of approximately $45^{\circ}$ for this analysis. Individuals were identified on-site when possible using a magnifying glass and photographed with a high resolution camera for further analysis and identification. The data were collected with use of daily observations between $10 \mathrm{a}$.m. and 2 p.m. for approximately 15 minutes on each brushwood pile.

The fauna was classified according to order and the number of occurring taxonomic units was quantified within each order. The fauna found in the brushwood was identified to be the lowest possible taxonomic level.

Specific richness was evaluated according to the number of taxonomic units of each order for each survey through the rarefaction curves obtained in PAST version 2.17, according to the Mao Tau method. These curves estimate the fauna taxonomic unit richness in comparison with each monitored period (Gotelli \& Colwell, 2001).

The average richness values of taxonomic units in each order of each survey did not present normal distribution, which was verified by the Shapiro-Wilk and Anderson Darling tests applied in Assistat version 7.7. Thus, they were subjected to the non-parametric Kruskal-Wallis test $(\mathrm{p}<0.05)$ to compare the mean values between the surveys.

The frequency of the different orders identified was calculated to analyze the degree of participation of each one, which is the relationship between the number of surveys in which each order occurs, and the total number of surveys.

\section{RESULTS}

We recorded 23 orders during monitoring, including insects, arachnids, amphibians, reptiles, mollusks, oligoquettes and diplopods (Table 1). The most representative classes were Insecta, making up $55.5 \%$ of the total, followed by Arachnida with $20.6 \%$ and Amphibia with $10.3 \%$.

The order with the largest number of taxonomic units was Orthoptera (2), followed by the other orders which were equivalent, with one record in the first survey. The main orders in the second survey were Araneae (4) and Orthoptera (4), followed by Anura (3). There was a predominance of Araneae (5), Hymenoptera (5), Anura (2) and Coleoptera (2) in the third evaluation. Hemiptera (5), Hymenoptera (4) and Orthoptera (3) were among the most representative orders in the fourth survey. The most significant orders in the fifth evaluation were Araneae (6), Hymenoptera (5) and Orthoptera (3), while in the last survey there was a predominance of Hymenoptera (7), Anura (6) and Araneae (5). 
Table 1. Classes of animals (in alphabetical order) followed by the respective orders and taxonomic units recorded during brushwood transposition surveys in a mining area in Guaíba County, Rio Grande do Sul, Brazil.

\begin{tabular}{|c|c|c|c|c|c|c|c|c|c|}
\hline \multirow{2}{*}{ Class } & \multirow{2}{*}{ Order } & \multicolumn{8}{|c|}{ Taxonomic units recorded by survey } \\
\hline & & S1 & S2 & S3 & S4 & S5 & S6 & Total & $\%$ \\
\hline \multirow{2}{*}{ Amphibia } & Anura & 1 & 3 & 2 & 2 & 1 & 6 & 15 & 9.7 \\
\hline & Gymnophiona & 0 & 0 & 0 & 0 & 0 & 1 & 1 & 0.6 \\
\hline \multirow{3}{*}{ Arachnida } & Araneae & 1 & 4 & 5 & 2 & 6 & 5 & 23 & 14.8 \\
\hline & Opiliones & 0 & 1 & 0 & 0 & 2 & 3 & 6 & 3.9 \\
\hline & Scorpiones & 1 & 1 & 0 & 1 & 0 & 0 & 3 & 1.9 \\
\hline Chilopoda & Scolopendromorpha & 0 & 0 & 0 & 0 & 0 & 1 & 1 & 0.6 \\
\hline Entognatha & Collembola & 0 & 0 & 0 & 0 & 1 & 1 & 2 & 1.3 \\
\hline Diplopoda & Spirobolida & 1 & 0 & 1 & 1 & 1 & 1 & 5 & 3.2 \\
\hline Gastropoda & Pulmonata & 0 & 1 & 1 & 0 & 1 & 0 & 3 & 1.9 \\
\hline \multirow{10}{*}{ Insecta } & Blattodea & 1 & 2 & 0 & 2 & 2 & 3 & 10 & 6.5 \\
\hline & Coleoptera & 0 & 2 & 2 & 2 & 2 & 3 & 11 & 7.1 \\
\hline & Diptera & 0 & 1 & 0 & 0 & 2 & 2 & 5 & 3.2 \\
\hline & Hemiptera & 0 & 2 & 1 & 5 & 1 & 1 & 10 & 6.5 \\
\hline & Hymenoptera & 1 & 2 & 5 & 4 & 5 & 7 & 24 & 15.5 \\
\hline & Isoptera & 1 & 1 & 1 & 1 & 1 & 1 & 6 & 3.9 \\
\hline & Lepidoptera & 0 & 1 & 0 & 0 & 0 & 1 & 2 & 1.3 \\
\hline & Mantodea & 0 & 0 & 0 & 1 & 0 & 0 & 1 & 0.6 \\
\hline & Orthoptera & 2 & 4 & 0 & 3 & 3 & 2 & 14 & 9.0 \\
\hline & Phasmatodea & 0 & 1 & 0 & 0 & 1 & 1 & 3 & 1.9 \\
\hline Malacostraca & Isopoda & 1 & 1 & 0 & 1 & 1 & 1 & 5 & 3.2 \\
\hline Oligochaeta & Haplotaxida & 0 & 0 & 0 & 0 & 1 & 1 & 2 & 1.3 \\
\hline \multirow{2}{*}{ Reptilia } & Squamata & 0 & 0 & 0 & 0 & 0 & 1 & 1 & 0.6 \\
\hline & Lacertilia & 0 & 0 & 0 & 1 & 0 & 1 & 2 & 1.3 \\
\hline Total & & 10 & 27 & 18 & 26 & 31 & 43 & 155 & \\
\hline
\end{tabular}

S1: October/2016; S2: December/2016; S3: February/2017; S4: April/2017; S5: June/2017; S6: August/2017.

The rarefaction curves showed the presence of a gradual increase in the number of taxonomic units (Figure 3). The second survey (Survey 2) stood out compared to the others by presenting a high number of taxonomic units and orders when compared with subsequent surveys (Survey 3 and Survey 4) (Table 1). The last survey (Survey 6) recorded the largest number of taxonomic units belonging to the largest number of orders. The curve for this survey showed no stabilization, which indicates a continuity trend in the increase of taxonomic units over time.

An increase in the occupation of organisms of different orders was observed, particularly in survey 5 (June/2017).
The means evaluated by the Kruskal-Wallis test differed significantly from the fifth survey (Survey 5 ), remaining constant until the last evaluation (Figure 4).

The orders with the highest absolute frequency in the six surveys were Anura (frogs and tree frogs), Araneae (spiders), Hymenoptera (ants), and Isoptera (termites), which were present in all surveys (Figure 5). In addition to these orders, we highlight the frequency of Isopoda (Porcellionidae) and Collembola (terrestrial microarthropods) due to their occurrence in large groups, as well as Coleoptera (beetles) found in different stages of their life cycle. 


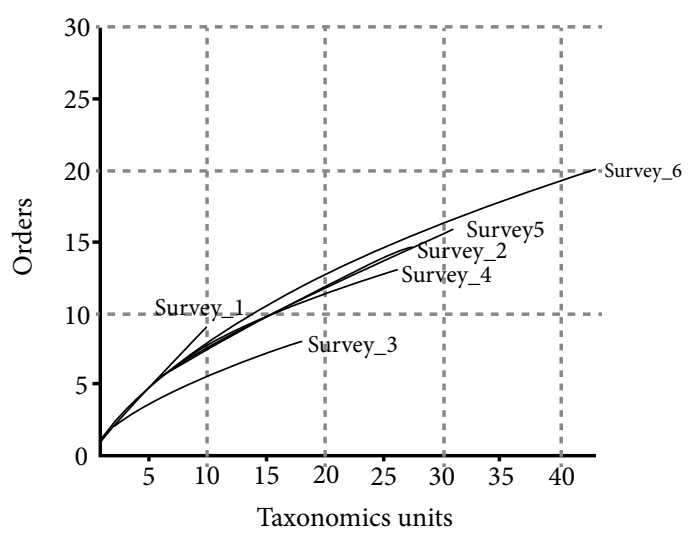

Figure 3. Rarefaction curves of fauna taxonomic units found in the brushwood sites corresponding to each survey in a mining area in Guaíba County, Rio Grande do Sul, Brazil.

Survey n: corresponds to each of the six performed surveys.

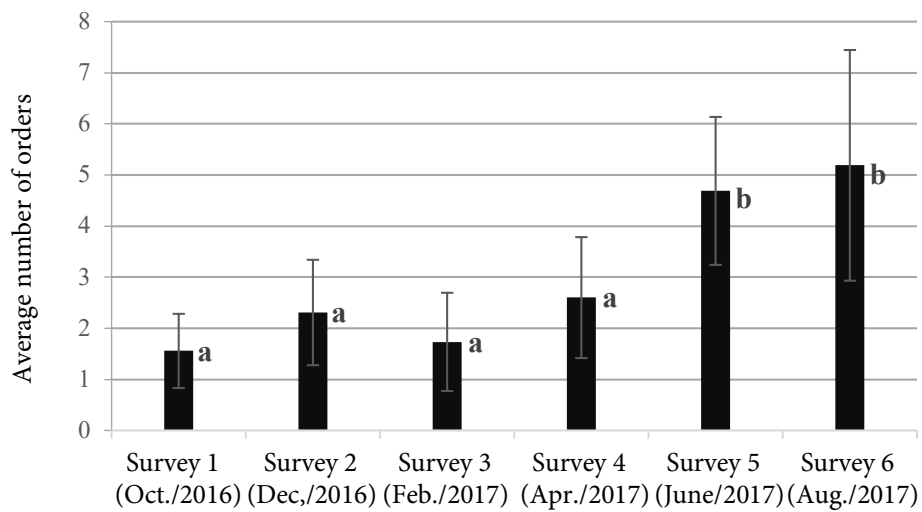

Figure 4. Diversity of the fauna measured by the average number of orders found per brushwood in each survey in a mining area in Guaíba County, Rio Grande do Sul, Brazil.

Means followed by the same letter did not differ statistically according to the Kruskal-Wallis test $(p \leq 0.05)$.

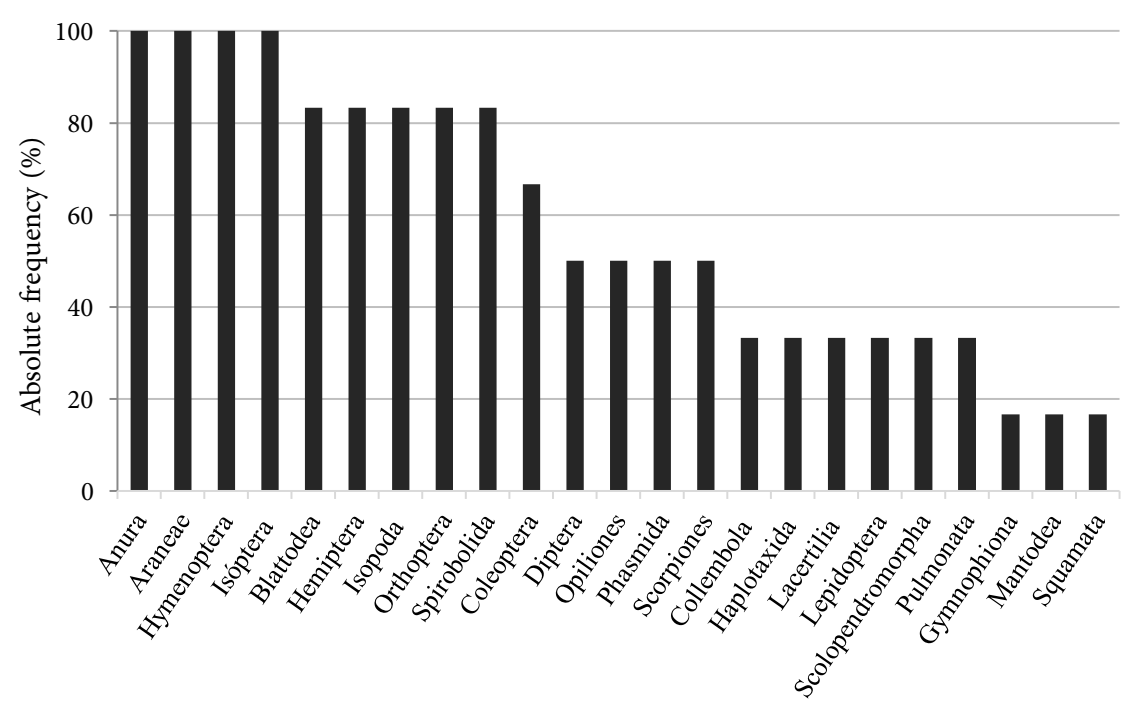

Figure 5. Absolute frequency of the orders found during the monwitoring period in the brushwood sites in a mining area in Guaíba County, Rio Grande do Sul, Brazil. 


\section{DISCUSSION}

An increase in the occurrence of organisms of different orders was observed starting from survey 4 (April/2017). The degradation caused in mining areas is severe and causes major changes, especially in the biological properties of the soil. Thus, the return of soil fauna tends to be slow and gradual. Soil invertebrates are severely damaged, but restoration aimed at increasing organic matter tends to promote short and long term increases in soil microbial biomass, which condition the maintenance of other subsequent fauna communities (Nunes et al., 2012).

Increases in the number of orders is related to decomposing plant material over the monitored period and consequently to an improvement in the environmental conditions of a substrate which previously had no vegetation cover. The quality of the vegetation cover, which acts as a source of nutrients and shelter, is directly related to the richness of the edaphic fauna (Rovedder et al., 2009). Considering a year of brushwood transpositioning, it is possible to state that the technique becomes functional regarding the establishment of animals and organisms which coexist in the same habitat starting from the eighth month.

Anura occurred in all surveys, and the Physalaemus and Leptodactylus genera stood out among the most found taxonomic units. Physalaemus species are widely distributed in Brazil (Borges-Martins et al., 2007), inhabit open and anthropized areas, and reproduce in wetlands, dams and temporary lakes (Ribeiro et al., 2018). The diet of anurans is mainly composed of beetles, isoptera, hymenoptera and hemiptera (Leivas et al., 2018; Moser et al., 2017).

Leptodactylus species tend to breed in temporary pools or ponds (Ribeiro et al., 2018) or build foam nests when they need to decrease their reliance on aquatic environments in altered sites (Bardier et al., 2014), being considered generalists that are easily adapted to disturbed areas (Teles et al., 2018). Their diet includes coleoptera and hymenoptera (Costa et al., 2016). Borges-Martins et al. (2007) report that some anuran genera take refuge and forage under trunks and litter, among which are Physalaemus and Leptodactylus.

The lake next to the study area provides a favorable environment for nesting the aforementioned anuran species, while the galls provide a place for forage, where the occurrence of invertebrate animals which are part of the diets of both genera was verified. These anurans tend to attract new species of predators contributing to the complexification of the food chain.

In this context we can highlight the occurrence of a snake observed under the brushwood in the last survey. It was a Bothrops sp. (jararaca) belonging to the Squamata order.
Snakes beginning to appear may indicate that trophic levels of the food chain are being reestablished and evidence the presence of food supply, mainly related to the occurrence of anurans, which are part of the Bothrop diet (Bisneto \& Kaefer, 2019).

Like Anura, the Araneae, Hymenoptera and Isoptera orders were verified in all surveys (Figure 5) and have relevant ecological functions. These orders are constituents of the edaphic macrofauna and contribute to the main soil ecosystem functions (Kamau et al., 2017).

Spiders occupy various microhabitats from different natural environments and mainly feed on insects of the most varied orders. Their most important role is to control overpopulations of fauna groups that may destabilize the system (Cardoso et al., 2011). The Lycosidae family is constituted by a population of spiders associated with the brushwood. They are typical of open areas; however, they have also been observed to forage in litter looking for environments with greater food availability when there is a lack of prey (Francisco \& Lise, 2014), which in this case are provided by the brushwood. The data obtained by this author suggest that spider populations can be extinct in places where there is no possibility of refuge in extreme situations of environmental stress, which emphasizes the importance of brushwood.

Ants were responsible for the high frequency of the Hymenoptera order at the study site. Hymenoptera was among the most abundant order (Vergílio et al., 2013) in degraded areas under effect of restoration by brushwood transposition. The higher occurrence of ant species may be related to the higher accumulation of litter in the soil due to the decomposing brushwood, which is a nesting and foraging area for most species (Oliveira et al., 2016).

Ants are considered soil structuring (Forgarait, 1998) as they improve physicochemical aspects of the substrate, and are granivorous insects, capable of dispersing seeds of plant species (Hughes \& Westoby, 1992). The richness and diversity of ant species tends to increase according to the complexity of environments due to the greater availability of niches present (Oliveira et al., 2016; Rocha et al., 2015). As such, brushwood serves as an aggregator of ecological niches that complexify the ecosystem, while offering microhabitats which also did not previously exist in the area.

Termites (Isoptera order) were verified starting from the first survey. They act rapidly in brushwood decomposition and are considered ecosystem engineers (Dangerfield et al., 1998; Jouquet et al., 2014; Lavelle et al., 2006). This designation is due to its performance in direct benefits such as nutrient cycling, soil aeration, soil movement between layers, aggregate formation and decomposition of organic material (Ferreira et al., 2011). 
In addition, termites reduce the risk of erosion by producing burrows and underground nest structures that increase water infiltration and by producing stable soil aggregates that improve roughness by limiting superficial runoff (Evans et al., 2011). The change in soil characteristics provided by termite activity can promote necessary conditions for developing natural vegetation in previously degraded soils (Jouquet et al., 2014).

Porcellionidae, a terrestrial family of order Isopoda, were among the most important decomposers inhabiting the brushwood, having been observed since the first survey. They are described as saprophagous and primary decomposers, feeding on decaying plant material which has already suffered some microbial attack (Correia \& Andrade, 2008).

Although not among the most frequent orders found in the surveys, we highlight the occurrence of Coleoptera, represented by the beetles of the Scarabaeidae family. These insects were found at different stages of their life cycle, mainly represented by individuals in the larval phase who built tunnels and lodged in the 0 to $10 \mathrm{~cm}$ layer of the substrate. These insects move nutrients between soil layers and aid during cycling by building these tunnels and by telecoprism behavior (the act of burying excrement spheres throughout tunnels) (Silva et al., 2011).

More specific groups began to appear under the brushwood from the fifth assessment on, which was not registered until the eighth month of monitoring. This is the case of collembolans, which are mesofauna organisms that inhabit the soil-litter system and act on nutrient cycling, both in the decomposition of organic matter and in feeding fungi and bacteria (Bellini \& Zeppelini, 2009). They are sensitive to microclimatic variations such as temperature and humidity, which determine a favorable habitat for their reproduction and growth (Spiller et al., 2018). Therefore, if there are collembolans under the brushwood, there is a good indication that a microclimate which is favorable to the species is being provided. These insects still serve as food for other groups that are occurring in the brushwood such as spiders (Araneae) and beetles (Coleoptera), being essential in establishing trophic chains (Silva et al., 2013).

In a study assessing the immediate effect of brushwood transposition in the arthropod community associated with litter (mesofauna) in a degraded area in the Cerrado biome, an immediate effect of brushwood was observed under such populations, with increased abundance of arthropod fauna in the litter after transposition (Vergílio et al., 2013). This study observed an increase in the orders occurring in the brushwood one year after implantation, which was also observed in this study (Figure 4).

Brushwood tends to incorporate a new configuration into the area under restoration and offers more microhabitat options for soil invertebrate populations. When compared to traditional revegetation plantations, ecological restoration typically includes richness of invertebrate species associated with a more diverse habitat (Šálek et al., 2010).

It is expected that there will be complexification and strengthening processes of trophic chains in the area with the increase of soil macro and mesofauna, causing more fauna groups to be attracted and perform their ecological functions. As the decomposition process advances, brushwood tends to increase the litter and improves the fertility of this substrate through mineralizing nutrients. Thus, the seeds which may have been brought in by the fauna find a favorable environment for germination; a fact which previously did not exist in places where the brushwood was implemented since there were no basic supplies such as humidity.

Thus, brushwood transpositioning is a technique capable of promoting roughness, not to modify its respective topography, but as elements that stand out horizontally and vertically in the local landscape. This roughness results in benefits for establishing soil fauna in degraded areas, mainly by attenuating the incidence of light and by conditioning a higher nutrient and humidity accumulation (Aumond et al., 2012; Aumond \& Maçaneiro, 2014).

\section{CONCLUSIONS}

There was a gradual increase in the occurrence of groups of fauna associated with brushwood transpositions within a year of monitoring, indicating their attractiveness. Considering the monitored period, the brushwood areas provided new habitats and coexistence between different fauna groups.

The methodology developed for data collection mainly proved to be applicable due to its non-destruction of the samples and low interference in the local fauna communities. In addition, it assisted in monitoring indicators in ecological restoration projects, in view of their rapid assessment.

\section{ACKNOWLEDGEMENTS}

The authors thank CMPC Celulose Riograndense for the financial support of this project. The authors also thank Coordenação de Aperfeiçoamento de Pessoal de Nível Superior (CAPES) and Conselho Nacional de Desenvolvimento Científico e Tecnológico (CNPq) for the Master's degree grant concerning the Graduate Program for Agricultural Engineering of Universidade Federal de Santa Maria (UFSM) provided to the first author.

\section{SUBMISSION STATUS}

Received: 26 Apr. 2018

Accepted: 3 Nov. 2019

Associate editor: Juliana Müller Freire 


\section{CORRESPONDENCE TO}

\section{Ana Paula Rovedder}

Universidade Federal de Santa Maria (UFSM), Av. Roraima, 1.000, Camobi, CEP 97105-900, Santa Maria, RS, Brasil

e-mail: anarovedder@gmail.com

\section{FINANCIAL SUPPORT}

CMPC Celulose Riograndense, Coordenação de Aperfeiçoamento de Pessoal de Nível Superior (CAPES) and Conselho Nacional de Desenvolvimento Científico e Tecnológico (CNPq).

\section{REFERENCES}

Alvares CA, Stape JL, Sentelhas PC, Gonçalves JLM, Sparovek G. Köppen's climate classification map for Brazil. Meteorologische Zeitschrift 2013; 22(6): 711728. 10.1127/0941-2948/2013/0507

Aumond JJ, Loch C, Comin JJ. Abordagem sistêmica e o uso de modelos para recuperação de áreas degradadas. Revista Árvore 2012; 36(6): 1099-1118. 10.1590/S0100-67622012000600011

Aumond JJ, Maçaneiro JP. Abordagem sistêmica e aplicação de rugosidades para desencadear propriedades emergentes em restauração de solos degradados. Ciência Florestal 2014; 24(3): 759-770. 10.1590/1980-509820142403023

Bardier C, Canavero A, Maneyro R. Temporal and spatial activity patterns of three species in the Leptodactylus fuscus group (Amphibia, Leptodactylidae). South American Journal of Herpetology 2014; 9(2): 106-113. 10.2994/SAJH-D-13-00036.1

Bellini BC, Zeppelini D. Registros da fauna de Collembola (Arthropoda, Hexapoda) no estado da Paraíba, Brasil. Revista Brasileira de Entomologia 2009; 53(3): 386-390. 10.1590/S008556262009000300012

Bisneto PF, Kaefer IL. Reproductive and feeding biology of the common lancehead Bothrops atrox (Serpentes, Viperidae) from central and southwestern Brazilian Amazonia. Acta Amazonica 2019; 49(2): 105-113. 10.1590/1809-4392201802371

Borges-Martins M, Colombo P, Zank C, Becker FG, Melo MTQ. Anfíbios. In: Becker FG, Ramos RA, Moura LA. Biodiversidade: regióes da Lagoa do Casamento e dos Butiazais de Tapes, planície costeira do Rio Grande do Sul. Brasília: Ministério do Meio Ambiente; 2007. p. 276-291.

Cabral LN, Albuquerque HN. Impactos socioambientais com a extração de minérios em uma área rural de Campina Grande-PB. Revista de Biologia e Farmácia 2012; 8(2): 76-85.

Cardoso P, Pekár S, Jocqué R, Coddington JA. Global patterns of guild composition and functional diversity of spiders. Plos One 2011; 6(6): e21710. 10.1371/journal.pone.0021710

Correia MEF, Andrade AG. Formação de serapilheira e ciclagem de nutrientes. In: Santos GA, Silva LS, Canellas LP, Camargo FAO. Fundamentos da matéria orgânica do solo: ecossistemas tropicais e subtropicais. 2nd ed. Porto Alegre: Metrópole; 2008. p. 137-158.

Costa DFS, Oliveira JCD, Oliveira JF, Chaves MF, Silva JN, Sousa TP. Dieta de Leptodactylus macrosternum (Amphibia; Anura; Leptodactylidae) no Sertão da Paraíba, Brasil. Revista Verde de
Agroecologia e Desenvolvimento Sustentável 2016; 11(4): 123-128. $10.18378 /$ rvads.v11i4.4372

Dangerfield JM, McCarthy TS, Ellery WN. The mound-building termite Macrotermes michaelseni as an ecosystem engineer. Journal of Tropical Ecology 1998; 14(4): 507-520.

Evans TA, Dawes TZ, Ward PR, Lo N. Ants and termites increase crop yield in a dry climate. Nature Communication 2011; 2: 262. $10.1038 /$ ncomms 1257

Felker RM, Rovedder APM, Longhi SJ, Araujo EF, Stefanello MM, Silva JCC Jr, Procknow D et al. Regeneração natural em área sob domínio de bambu, no sul do Brasil. Revista de Ciências Agrárias 2018; 41(1): 82-92. 10.19084/RCA17100

Ferreira EVO, Martins V, Inda AV Jr, Giasson E, Nascimento PC. Ação dos térmitas no solo. Ciência Rural 2011; 41(5): 804-811. 10.1590/S0103-84782011005000044

Forgarait PJ. Ant biodiversity and its relationship to ecosystem functioning: a review. Biodiversity \& Conservation 1998; 7: 1221-1244. 10.1023/A:1008891901953

Fragoso RO, Carpanezzi AA, Zuffellato-Ribas KC, Koehler HS. Forestry restoration in abandoned pastures of Urochloa by different sizes of brushwood. Cerne 2017; 23(1): 85-93. 10.1590/01047760201723012276

Francisco RC, Lise AA. Aranhas como ferramenta diagnóstica em trabalhos ambientais. Rïga: Novas Edições Acadêmicas; 2014.

Gotelli NJ, Colwell RK. Quantifying biodiversity: procedures and pitfalls in the measurement and comparison of species richness. Ecology Letters 2001; 4(4): 379-391. 10.1046/j.1461-0248. 2001.00230.x

Hughes L, Westoby M. Effect of diaspore characteristics on removal of seeds adapted for dispersal by ants. Ecology 1992; 73: 1300-1312. $10.2307 / 1940677$

Jesus EN, Santos TS, Ribeiro GT, Orge MDR, Amorim VO, Batista RCRC et al. Regeneração natural de espécies vegetais em jazidas revegetadas. Floresta e Ambiente 2016; 23(2): 191-200. 10.1590/ 2179-8087.115914

Jouquet P, Blanchart E, Capowiez Y. Utilization of earthworms and termites for the restoration of ecosystem functioning. Applied Soil Ecology 2014; 73(1): 34-40. 10.1016/j.apsoil.2013.08.004

Kamau S, Barrios E, Karanja NK, Ayuke FO, Lehmann J. Soil macrofauna abundance under dominant tree species increases along a soil degradation gradient. Soil Biology and Biochemistry 2017; 112: 35-46. 10.1016/j.soilbio.2017.04.016

Lavelle P, Decaëns T, Aubert M, Barot S, Blouin M, Bureau F, Margerie $\mathrm{P}$ et al. Soil invertebrates and ecosystem services. European Journal of Soil Biology 2006; 42(1): S3-S15. 10.1016/j.ejsobi.2006.10.002

Leivas PT, Leivas FWT, Campião KM. Diet and parasites of the anuran Physalaemus cuvieri Fitzinger, 1826 (Anura: Leiuperidae) from an Atlantic Forest fragment. Herpetology Notes 2018; 11: 109-113.

Mechi MA, Sanches DL. Impactos ambientais da mineração no estado de São Paulo. Estudos Avançados 2010; 24(68): 209-220. 10.1590/S0103-40142010000100016

Moser CF, Avila FR, Oliveira M, Tozetti AM. Diet composition and trophic niche overlap between two sympatric species of Physalaemus 
(Anura, Leptodactylidae, Leiuperinae) in a subtemperate forest of southern Brazil. Herpetology Notes 2017; 10: 9-15.

Nunes JS, Araujo ASF, Nunes LAPL, Lima LM, Carneiro RFV, Salviano AAC, Tsai SM. Impact of land degradation on soil microbial biomass and activity in northeast Brazil. Pedosphere 2012; 22(1): 88-95. 10.1016/S1002-0160(11)60194-X

Oliveira IRP, Ferreira AN, Viana AB Jr, Dantas JO, Santos MJC, Ribeiro MJB. Diversidade de formigas (Hymenoptera; Formicidae) edáficas em três estágios sucessionais de mata atlântica em São Cristóvão, Sergipe. Agroforestalis News 2016; 1(1): 48-58. 10.1590/ S1676-06032013000200013

Oliveira RE, Engel VL. A restauração florestal na Mata Atlântica: três décadas em revisão. Ciência, Tecnologia \& Ambiente 2017; 5(1): 40-48. 10.4322/2359-6643.05101

Oliveira Filho LCI, Baretta D, Santos JCP. Influência dos processos de recuperação do solo após mineração de carvão sobre a mesofauna edáfica em Lauro Müller, Santa Catarina, Brasil. Biotemas 2014; 27(2): 69-77. 10.5007/2175-7925.2014v27n2p69

Pais MP, Varanda EM. Arthropod recolonization in the restoration of a semideciduous forest in southeastern Brazil. Neotropical Entomology 2010; 39(2): 198-206. 10.1590/S1519-566X2010000200009

Podgaiski LR, Rodrigues GG. Leaf-litter decomposition of pioneer plants and detritivore macrofaunal assemblages on coal ash disposals in southern Brazil. European Journal of Soil Biology 2010; 46(6): 394-400. 10.1016/j.ejsobi.2010.09.001

Reis A, Bechara FC, Tres DR. Nucleation in tropical ecological restoration. Scientia Agricola 2010; 67(2): 244-250. 10.1590/S010390162010000200018

Reis A, Bechara FC, Tres DR, Trentin BE. Nucleação: concepção biocêntrica para a restauração ecológica. Ciência Florestal 2014; 24(2): 509-519. 10.5902/1980509814591

Ribeiro JAC, Ribeiro PHE, Lima JFS. Levantamento rápido dos anuros da área da cachoeira Roncadeira, Taquaruçu-Tocantins.
Arquivos de Ciências Veterinárias e Zoologia da Unipar 2018; 21 (1): 1-7. 10.25110/arqvet.v21i1.2018.5721

Rocha WO, Dorval A, Peres Filho O, Vaez CA, Ribeiro ES. Formigas (Hymenoptera: Formicidae) bioindicadoras de degradação ambiental em Poxoréu, Mato Grosso, Brasil. Floresta e Ambiente 2015; 22(1): 88-98. 10.1590/2179-8087.0049

Rovedder APM, Eltz FLF, Drescher MS, Schenato RB, Antoniolli ZI. Organismos edáficos como bioindicadores da recuperação de solos degradados por arenização no bioma Pampa. Ciência Rural 2009; 39(4): 1061-1068. 10.1590/S0103-84782009005000023

Šálek M, Hendrychová M, Řehoř M. Breeding habitat of sparrowhawks, Accipiter nisus on spoil heaps after coal mining. Acta Oecologica 2010; 36(2): 197-201. 10.1016/j.actao.2009.12.006

Silva PG, Vaz-De-Mello FZ, Di Mare RA. Guia de identificação das espécies de Scarabaeinae (Coleoptera: Scarabaeidae) do município de Santa Maria, Rio Grande do Sul, Brasil. Biota Neotropica 2011; 11(4): 329-345. 10.1590/S1676-06032011000400027

Silva RF, Corassa GM, Bertollo GM, Santi AL, Steffen RB. Fauna edáfica influenciada pelo uso de culturas e consórcios de cobertura do solo. Pesquisa Agropecuária Tropical 2013; 43(2): 130-137. 10.1590/S1983-40632013000200001

Spiller MS, Spiller C, Garlet J. Arthropod bioindicators of environmental quality. Revista Agro@mbiente On-line 2018; 12(1): 425-441. 10.18227/1982-8470ragro.v12i1.4516

Teles DA, Rodrigues JK, Teixeira AM, Araujo-Filho JA, Sousa JGG, Ribeiro SC. Diet of Leptodactylus macrosternum (MirandaRibeiro 1926) (Anura: Leptodactylidae) in the Caatinga domain, Northeastern Brazil, Neotropical Region. Herpetology Notes 2018; 11: 223-226.

Vergílio PCB, Knoll FRN, Mariano DS, Dinardi NM, Ueda MY, Cavassan O. Effect of brushwood transposition on the leaf litter arthropod fauna in a cerrado area. Revista Brasileira de Ciência do Solo 2013; 37(5): 1158-1163. 10.1590/S0100-06832013000500005 